\begin{tabular}{|c|c|c|}
\hline & Int.J.Curr.Microbiol.App.Sci (2016) 5(3): 738-744 & \\
\hline & International Journal of Current Microbiology and Applied Sciences & \\
\hline & ISSN: 2319-7706 Volume 5 Number 3(2016) pp. 738-744 & \\
\hline EXCELLENT & Journal homepage: http://www.ijcmas.com & $\varepsilon$ \\
\hline PUBLISHERS & & whrwi.jemas.ce \\
\hline
\end{tabular}

Original Research Article

http://dx.doi.org/10.20546/ijcmas.2016.503.086

\title{
Prevalence of G6PD Deficiency among the Malaria Patients in Urban Kolkata, India - A Clinic Based Study
}

\author{
Moytrey Chatterjee ${ }^{1}$, Swagata Ganguly ${ }^{1,2}$, Pabitra Saha $^{1,3 *}$, \\ Dilip K. Bera ${ }^{5}$, Nandita Basu ${ }^{4}$ and Ardhendu K. Maji ${ }^{1}$ \\ ${ }^{1}$ Protozoology Unit, Department of Microbiology, Calcutta School of Tropical Medicine, 108, \\ C. R. Avenue, Kolkata 700 073, India \\ ${ }^{2}$ Department of Microbiology, NRS Medical College, 138 AJC Bose Road, \\ Kolkata 700 014, India \\ ${ }^{3}$ Department of Zoology, A. P. C. Roy Govt. College, Himachal Bihar, Matigara, Siliguri- 734 \\ 010, West Bengal, India \\ ${ }^{4}$ Director, Calcutta School of Tropical Medicine, 108, C. R. Avenue, Kolkata 700 073, India \\ ${ }^{5}$ Department of Microbiology, Calcutta School of Tropical Medicine, 108, C. R. Avenue, \\ Kolkata 700 073, India \\ *Corresponding author
}

\begin{tabular}{|c|c|}
\hline & A B S T R A C T \\
\hline Keywords & \multirow{4}{*}{$\begin{array}{l}\text { The estimation of G6PD deficiency (G6PDd) is an important aspect in the current situation } \\
\text { of malaria elimination which requires use of primaquine to prevent transmission of } P \text {. } \\
\text { falciparum and relapse of } P \text {. vivax. Long term use of primaquine can induce acute } \\
\text { hemolytic anemia in G6PD deficient cases. A very little information is available about the } \\
\text { prevalence of G6PDd among the malaria positive cases from India. The present study was } \\
\text { designed to evaluate the G6PDd among the malaria positive patients attending the Calcutta } \\
\text { School of Tropical Medicine. A total of } 583 \text { blood samples were collected from diagnosed } \\
\text { malaria cases. G6PDd was estimated by Dichloro-phenol-indophenol (DCIP) decolorizing } \\
\text { test. The mean age of recruited patients was } 28.6 \text { years ranging from } 4-70 \text { years. Out of } 583 \\
\text { patients tested, } 8(1.37 \%) \text { were found to be G6PD deficient. G6PDd was more prevalent in } \\
P \text {. vivax infected patients (2.3\%) than the } P \text {. falciparum ( }(0.4 \%) \text { (P-value }=0.0401) \text {. G6PD } \\
\text { deficiency was more prevalent in females }(2.06 \%) \text { than in males }(1.23 \%) \text {. The prevalence } \\
\text { of G6PDd among the study population is low, but before the long term treatment of } \\
\text { primaquine, G6PD deficiency test should be performed to avoid deaths due to primaquine } \\
\text { induced acute hemolytic anemia. }\end{array}$} \\
\hline $\begin{array}{l}\text { G6PD } \\
\text { deficiency, } \\
\text { Malaria, } \\
P . \text { falciparum, } \\
P . \text { vivax, India. }\end{array}$ & \\
\hline Arti & \\
\hline $\begin{array}{l}\text { Accepted: } \\
20 \text { Februar } \\
\text { Available } \\
10 \text { March }\end{array}$ & \\
\hline
\end{tabular}

\section{Introduction}

The glucose-6-phosphate dehydrogenase (G6PD) deficiency is an erythroenzymopathological disease in humans, affecting 400 million people worldwide (Howes et al., 2012; Isaac et al., 2013). It is an $\mathrm{X}$-linked recessive, heritable, genetic disorder, due to mutations in the G6PD gene, which cause functional variants with many biochemical and clinical phenotypes. The G6PD gene is situated at the telomeric region of the $\mathrm{X}$ chromosome (band $\mathrm{Xq} 28$ ) which consists of 13 exons and 12 introns. It 
encodes 515 amino acids and a GC-rich (more than 70\%) promoter region (Ruwende and Hil, 1981). Approximately 140 mutations or combinations of mutations responsible for this deficiency have been described (Zhao et al., 2010; Manganelli et al., 2013). Glucose-6-phosphate dehydrogenase (G6PD), a metabolic enzyme, plays an active role in survival of erythrocytes. It catalyses the first reaction in the pentose phosphate pathway, providing reducing power to all cells in the form of NADPH (reduced form of nicotinamide adenine dinucleotide phosphate). NADPH enables cells to counterbalance oxidative stress triggered by oxidant agents. In individuals whose G6PD enzyme is deficient, different kinds of haemolysis from mild to severe are seen bound to differences in variants of the disease (Beutler, 1983; Luzzatto 1989).

The disease has been reported nearly from all geographical locations (Tishkoff et al., 2001); however its prevalence is highest in areas where malaria had been endemic for long time like Africa, Central and South America, while in malaria non-endemic regions prevalence is low, suggesting the relationship between G6PD deficiency and malaria (Haworth et al., 1988; WHO, 2003).

One of the significant global public health challenges is controlling malaria, especially in low transmission regions which are seen as prime areas for malaria elimination (WHO, 2011). Therefore, World Health Organization (WHO) strongly recommends the use of primaquine (PQ) for both transmission blocking of Plasmodium falciparum, because it kills mature gametocytes, and as anti-relapse treatment against Plasmodium vivax by killing liver hypnozoites (White, 2008; Wells et al., 2010). But the use of PQ without knowing the G6PD level may lead to acute haemolytic anaemia (AHA) in G6PD deficient patients (Howes et al., 2013) which may even cause death. Therefore, screening of G6PD deficiency is very important for malaria patients before treatment with long term PQ.

The report of G6PD deficiency in the malaria endemic areas of India is very few, particularly from West Bengal. Therefore, the present study was conducted to detect the prevalence of G6PD deficiency among the malaria patients (both $P$. falciparum and $P$. vivax) of urban Kolkata, West Bengal who were diagnosed at the Malaria Clinic of Calcutta School of Tropical Medicine.

\section{Materials and Methods}

\section{Study Population and Collection of Blood Sample}

The present study was conducted from 2012 to 2015 at the Malaria Clinic of Calcutta School of Tropical Medicine, Kolkata. In routine practice febrile patients attending the clinic were examined clinically and thick and thin peripheral blood smear were collected on same glass slide. Both the smears were stained with Giemsa and examined for malarial parasite. Three $\mathrm{ml}$ of EDTA blood was collected from known microscopically positive malaria patients for estimation of haemoglobin and qualitative test for screening of G6PD deficiency. Inform consent was obtained from the adult patients and from the guardians of the patients below the age of 14 years before collection of venous blood.

\section{Estimation of Haemoglobin}

Haemoglobin $(\mathrm{Hb})$ level of recruited patients was measured by Cyanmethemoglobin method. $20 \mu \mathrm{l}$ of EDTA blood was drawn with the help of 
haemoglobin pipette and transferred into a test tube containing $5 \mathrm{ml}$ of Drabkin's solution (it contains potassium cyanide, potassium ferricyanide, and potassium phosphate). The blood and Drabkin's solution were mixed thoroughly and kept undisturbed for 5 mins. The absorbance of the sample was measured in a photoelectric colorimeter at $540 \mathrm{~nm}$ after adjusting the OD at 0 by using Drabkin's solution as blank. The standard Cyanmethemoglobin solution contains $14.8 \mathrm{~g}$ of the haemoglobin/ $100 \mathrm{ml}$. The corresponding blood haemoglobin in $\mathrm{g} / 100 \mathrm{ml}$ was obtained by multiplying the concentration of the standard solution by dilution factor.

\section{Qualitative Test for G6PD Deficiency}

The samples were screened for red cell G6PD deficiency by Dichloro phenol indophenol (DCIP) decolorizing test. For this test HAMOPAK G6PD test kit (Reckon Diagnostic P. Ltd., Vadodara, India) was used and test was performed as per manufacturer instruction. In this test NADPH evolved through the action of G6PD reduces the dye DCIP into a colourless state (DCIPH2). The rate and the degree of this decolorization are proportional to the G6PD activity in the RBCs. Phenazone methosulphate (PMS) is used as an electron carrier between NADPH and 2, 6 DCIP in this test. At first $0.5 \mathrm{ml}$ of buffer was added to the Co-enzyme substrate and shaken well to allow complete dissolution. Then $20 \mu \mathrm{l}$ of whole blood was mixed with pre-cooled lysing reagent and stored in refrigerator $\left(2-4^{\circ} \mathrm{C}\right)$ for $10-15$ minutes. After that red cell haemolysate was transferred to the vial containing co-enzyme substrate solution and mixed well. The mixture was immediately overlaid by $1 \mathrm{ml}$ of inert oil and the vial was sealed tightly to make it air tight and incubated at $37^{\circ} \mathrm{C}$. The colour of the mixture changes initially from blue to brownish. In normal G6PD subjects, the decolourization of the mixture will occur within 30 - 60 minutes while it takes $2-24$ hours for G6PD deficient subjects.

\section{Statistical Analysis}

All data were entered and verified using Microsoft Excel software® 2007 and statistical analysis was done by Graph Pad InStat3 (version 3.06) statistical software. Chi-squared or Fisher's exact tests were used to assess significant differences in proportions. All reported P-values are twosided and were considered statistically significant if $<0.05$.P value.

\section{Results and Discussion}

\section{Demographics of Study Population}

From 2012 to 2015, a total of 583 malaria positive patients were recruited from the Malaria Clinic of Calcutta School of Tropical Medicine, Kolkata. The mean age was 28.67 years (SD: \pm 14.62$)$ with a range of 4 to 70 years, distributed as $14.6 \%$ was < 15 years, and $85.4 \%$ was $\geq 15$ years. The male: female ratio was 5.01:1. The demographic data and clinical parameters of the study groups are summarized in Table 1.

\section{Parasitological Parameters}

P. falciparum was present in 284 (48.7\%) and $P$. vivax in $299(51.3 \%)$ patients. Significant differences were found between $P$. falciparum and $P$. vivax infections for age (P <0.0008), sex ( $\mathrm{P}<0.009)$, and G6PD deficiency $(\mathrm{P}<0.0401)$ (Table 1).

\section{Haematological Parameters}

For all patients, the mean $\mathrm{Hb}$ concentration was $12.38 \mathrm{~g} / \mathrm{dL}$ (95\% CI: 12.19-12.58) and was significantly lower in females 11.83 
g/dL vs. males $12.84 \mathrm{~g} / \mathrm{dL}(\mathrm{P}<0.0001)$. But no significant difference was observed between the mean haemoglobin concentration of G6PD deficient cases 11.77 $\mathrm{g} / \mathrm{dL}$ and normal cases $12.42 \mathrm{~g} / \mathrm{dL}(\mathrm{P}<$ 0.1052).

\section{Prevalence of G6PD Deficiency}

Among the 583 patients screened for G6PD deficiency, $8(1.37 \%)$ cases were found G6PD deficient which includes 2 (25.0\%) female and $6(75.03 \%)$ male. The mean age of G6PD deficient cases were 35.0 years (SD: \pm 16.71 ) with range from 16 to 56 years. Mean haemoglobin concentration of G6PD deficient cases was $11.66 \mathrm{~g} / \mathrm{dL}$ (95\% CI: 11.09-12.23). Among the G6PD deficient cases $1(12.50 \%)$ case was $P$. falciparum positive and 7 (87.50\%) cases were $P$. vivax positive. The occurrence of G6PD deficient cases was higher in $P$. vivax malaria cases $(2.3 \%)$ than $P$. falciparum cases $(0.4 \%)$.

Due to introduction of Artimisinine Combination Therapies (ACTs) the total number of $P$. falciparum cases decreased from 226 million in 2008 to 201 million in 2014. But the number $P$. vivax infection remained more or less same globally (WHO, 2009; WHO, 2015a). The main problem in controlling $P$. vivax cases is relapse due to presence of dormant hypnozoite stage in liver. PQ is the only known drug effective in hypnozoite (White, 2008) when treated with a longer duration.

As per WHO, $P$. vivax cases are now treated with PQ for 14 days in addition with schizonticidal drug like CQ in areas where $\mathrm{CQ}$ is effective. Recently WHO targeted a year wise goal to eliminate malaria from 10 countries by 2020 , from 20 countries by 2025 and from 35 countries by 2030 (WHO, 2015b). To achieve this PQ has an important role as gametocidal agent for $P$. falciparum for transmission blocking and to kill hypnozoites of $P$. vivax and $P$. ovalae to prevent relapse (White, 2008; Maude et al., 2012). Use of long term PQ for $P$. vivax may lead to death due to AHA in G6PD deficient patients.

Table.1 Demographic and Biochemical Parameters of the Study Patients

\begin{tabular}{|c|c|c|c|c|}
\hline Patients characteristics & Total & P. falciparum & P. vivax & P-value \\
\hline Number of patients & 583 & 284 & 299 & - \\
\hline $\begin{array}{l}\text { Age (yrs) } \\
\text { Mean } \\
\text { Range } \\
\text { SD } \\
95 \% \text { CI }\end{array}$ & $\begin{array}{l}28.67 \\
4-70 \\
\pm 14.62 \\
27.49-29.86\end{array}$ & $\begin{array}{l}30.74 \\
4-70 \\
\pm 15.45 \\
28.94-32.54\end{array}$ & $\begin{array}{l}26.71 \\
5-68 \\
\pm 13.52 \\
25.18-28.25\end{array}$ & 0.0008 \\
\hline $\begin{array}{l}\text { Age category: no (\%) } \\
<15 \mathrm{yrs} \\
\geq 15 \mathrm{yrs}\end{array}$ & $\begin{array}{l}85(14.6) \\
498(85.4)\end{array}$ & $\begin{array}{l}37(13.1) \\
247(86.9) \\
\end{array}$ & $\begin{array}{l}48(16.1) \\
251(83.9)\end{array}$ & 0.347 \\
\hline Sex ratio (\% female) & 16.64 & 20.77 & 12.71 & 0.009 \\
\hline $\begin{array}{l}\text { Haemoglobin }(\mathrm{g} / \mathrm{dl}) \\
\text { Mean } \\
\text { Range } \\
\text { SD } \\
95 \% \text { CI }\end{array}$ & $\begin{array}{l}12.38 \\
7.85-17.04 \\
\pm 1.40 \\
12.19-12.58\end{array}$ & $\begin{array}{l}12.73 \\
10.60-14.90 \\
\pm 1.02 \\
12.54-12.92\end{array}$ & $\begin{array}{l}11.93 \\
7.85-17.04 \\
\pm 1.69 \\
11.57-1229\end{array}$ & 0.0001 \\
\hline G6PD deficiency: no (\%) & $8(1.37)$ & $1(0.4)$ & $7(2.3)$ & 0.0401 \\
\hline
\end{tabular}


Table.2 Age and Sex Wise Distribution of G6PDd Cases

\begin{tabular}{|l|l|}
\hline Characteristics & \multicolumn{1}{|c|}{ Study patients $(\mathbf{n}=\mathbf{8})$} \\
\hline Sex: no $(\%)$ & \\
Male & $6(75.0)$ \\
Female & $2(25.0)$ \\
\hline Age (yrs) & 35.0 \\
Mean & $16-56$ \\
Range & \pm 16.71 \\
SD & $21.02-48.97$ \\
95\% CI & \\
Haemoglobin $(\mathrm{g} / \mathrm{dl})$ & 11.66 \\
Mean & $10.30-12.4$ \\
Range & \pm 0.68 \\
SD & $11.09-12.23$ \\
95\% CI & \\
\hline Malaria parasites & $1(12.50)$ \\
P. falciparum & $7(87.50)$ \\
$P$. vivax & \\
\hline
\end{tabular}

Prevalence of G6PD deficiency in India varies between $0-28 \%$ (Basin and Walter, 2001). In the present study an overall prevalence of G6PDd was $1.37 \%$ among the malaria positive patients attending the Malaria Clinic of Calcutta School of Tropical Medicine, Kolkata. Our finding was in accordance to Pao et al., 2005 (Pao et al., 2005) who showed prevalence of $2.0 \%$ in Indian general population in his retrospective hospital based study. Jain, 1992 (Jain, 1992) found prevalence of $1.8 \%$ in Udaipur Rajasthan in malaria endemic population. We also found that, the deficiency was more prevalent in females $(2.06 \%)$ than in males $(1.23 \%)$ which is contradictory to the previous studies by $\mathrm{Pao}$ et al., 2005 (2.8\% male, $1.1 \%$ female) and by Gupte et al., 2005 (27.9\% male, 9.7\% females) in Vataliya Prajapati communities from Surat. But, Ramadevi et al., 1994 found equal prevalence of G6PD deficiency in males and females and Wang et al., 2009 indicated that sex was not a significant predictor associated with actual G6PD enzyme levels (Wang et al., 2009). This can be explained by the fact that hetrozygously deficient women have a mixed population of erythrocytes, owing to random inactivation of one of the two x-chromosomes, known as lionization (Davidson, 1963). Due to lionization some of the heterozygote females are deficient and others are normal (Davidson, 1963).

In conclusion, in the present study G6PD level was estimated among the known malaria patients only and it was a clinic based study. So it does not reflect the overall prevalence among the entire population. But the results showed that $1.37 \%$ malaria positive patients were G6PDd. So before giving PQ treatment for longer duration G6PD level should be analyzed.

\section{Authors' Contribution}

AKM designed the study; MC, SG, PS, clinically examined, recruited patients, collected the blood samples; SG, DKB provided the treatment, MC, SG, PS assessed laboratory diagnostics; MC, PS, $\mathrm{NB}$ perform the data analysis and interpretation. AKM, PS, SG, NB prepared the manuscript. 


\section{References}

Basin, M.K, Walter, H., 2001. Genetics of castes and tribs in India. Delhi: Kamla -Raj Enterprises.

Beutler, E. 1983. Glucose-6-phosphate dehydrogenase deficiency. The Metabolic Basis of Inherited Disease, Vol. Fifth edition (JB Stanbury JW, DS Fredrickson, and J Goldstein), pp. 1629-1653. McGraw-Hill, New York.

Davidson, R.G., 1963. Demonstration of two population of cells in the human female heterozygous for glucose $-6-$ phosphate dehydrogenase variants. Proc. Natl. Acad. Sci., 50: 481-485.

Gupte, S.C., Patel, P.U., Ranat, J.M. 2005. G6pd Deficiency In Vataliya Prajapati Community Settled In Surat. Ind. J. Med. Sci., 59(2: 51-56.

Haworth, J., Wernsdorfer, W., Mc Gregor, I. 1988. The global distribution of malaria and the present control effort. Malaria: Principles and Practice of Malariol., Vol. 2. pp. 1379-1420.

Howes, R.E., Battle, K.E., Satyagraha, AW., Baird, J.K., Hay, S.I. 2013. G6PD deficiency: global distribution, genetic variants and primaquine therapy. $A d v$. Parasitol., 8: 133-201.

Howes, R.E., Piel, F.B., Patil, A.P., Nyangiri, O.A., Gething, P.W., Dewi, M., Hogg, M.M., Battle, K.E., Padilla, C.D., Baird, J.K., Hay, S.I. 2012. G6PD deficiency prevalence and estimates of affected populations in malaria endemic countries: a geostatistical model-based map. PLoS. Med., $\quad$ 9(11): 1001339. doi:10.1371/journal.pmed.1001339

Isaac, I., Mainasara, A., Erhabor, O., Omojuyigbe, S., Dallatu, M., Bilbis, L., Adias, T. 2013. Glucose-6phosphate dehydrogenase deficiency among children attending the Emergency Paediatric Unit of Usmanu
Danfodiyo University Teaching Hospital, Sokoto, Nigeria. Int. J. Gen. Med., 6: 557-562.

Jain, R.C. 1992. G6PD deficiency in malaria endemic areas of Udaipur District in Rajasthan. J. Assoc. Physicians. India, 40: 66-663.

Luzzatto, La, M.A., 1989. Glucose-6phosphate dehydrogenase deficiency. The Metabolic of Inherited Disease, Vol. Sixth edition (CR Scriver AB, WS Sly, and D Valle), pp. 2237-2265. McGraw-Hill, New York.

Malaria situation, National vector borne disease control programme. 2014. http://nvbdcp.gov.in/doc/ malariasituation -Nov15.pdf.

Manganelli, G., Masullo, U., Passarelli, S., Filosa, S. 2013. Glucose-6-phosphate dehydrogenase deficiency: disadvantages and possible benefits. Cardiovasc. Hematol. Disord. Drug. Targets, 13(1): 73-82.

Maude, R.J., Socheat, D., Nguon, C., Saroth, P., Dara, P., Li, G., Song, J., Yeung, S., Dondorp, A.M., Day, N.P., White, N.J., White, L.J. 2012. Optimising strategies for Plasmodium falciparum malaria elimination in Cambodia: primaquine, mass drug administration and artemisinin resistance. PLoS. One, 7: 37166.

Pao, M., Kulkarni, A., Gupta, V., Kaul, S., Balan, S. 2005. Neonatal screening for glucose-6-phosphate dehydrogenase deficiency. Ind. J. Pediatr., 72: 835-7.

Ramadevi, R., Savithri, H.S., Devi, AR., Bittles, A.H., Rao, N.A. 1994. An unusual distribution of glucose-6phosphate dehydrogenase deficiency of south Indian Newborn population. Ind. J. Biochem. Biophys., 31: 358360.

Ruwende, C., Hill, A. 1998. Glucose-6phosphate dehydrogenase deficiency and malaria. J. Mol. Med., 76: 581- 
588.

Tishkoff, S.A., Varkonyi, R., Cahinninan, N., Abbes, S., Argyro-poulos, G., StroBisol, G., Drousiotou, A., Dangerfield, A.G. 2011. Haplotype diversity and linkage disequilibrium at human G6PD: recent origin of allels that confer malarial resistance. Sci., 293: 455-462.

Wang, F.L., Boo, N.Y. 2009. Comparison of detection of glucose-6-phosphate dehydrogenase deficiency using fluorescent spot test, enzyme assay and molecular method for prediction of severe neonatal hyperbilirubinaemia. Singapore. Med. J., 50(1): 6-67.

Wells, T.N., Burrows, J.N., Baird, J.K. 2010. Targeting the hypnozoite reservoir of Plasmodium vivax: the hidden obstacle to malaria elimination. Trends. Parasitol., 26: 145-151.

White, N.J. 2008. The role of anti-malarial drugs in eliminating malaria. Malar. J., 7(Suppl 1): S8.

WHO. 2003. The world health report 2003:
B., Lefranc, G., Loiselet, J., Piro, A., Stoneking, M., Tagarelli, A., Tagarelli, G., Touma, E.H., Williams, S.M., Andrew, G., Clark, shaping the future. World Health Organization, Geneva, Switzerland. Annex table Vol.2, pp. 156.

WHO. 2009. World Malaria Report, 2009. World Health Organization, Geneva, Switzerland.

WHO. 2011. WHO: Global plan for artemisinin resistance containment (GPARC). World Health Organization, Geneva, Switzerland.

WHO. 2015a. World malaria Report, 2015. World Health Organization, Geneva, Switzerland.

WHO. 2015b. Global technical strategy for malaria, 2016-2030. World Health Organization, Geneva, Switzerland.

Zhao, X., Li, Z., Zhang, X. 2010. G6PDMutDB: a mutation and phenotype database of glucose-6-phosphate (G6PD) deficiency. J. Bioinform. Comput. Biol., 8(Suppl 1): 101-109.

\section{How to cite this article:}

Moytrey Chatterjee, Swagata Gangulya, Pabitra Sahaa, Dilip K. Bera, Nandita Basu, and Ardhendu K. Maji. 2016. Prevalence of G6PD Deficiency Among the Malaria Patients in Urban Kolkata, India - A Clinic Based Study. Int.J.Curr.Microbiol.App.Sci. 5(3): 738-744. doi: http://dx.doi.org/10.20546/ijcmas.2016.503.086 